The assistance of Messrs. J. Kuiper and T. O'Brien in critically examining this technique is gratefully acknowledged.

$$
\text { B. S. Janes }
$$

Merrindale Biological Research Station,

Imperial Chemical Industries of

Australia and Now Zealand, Ltd., Croydon, Victoria.

${ }^{1}$ Leben, C., Phytopath., 42, 352 (1952).

Isaac, P. K., Phytopath., 50, 474 (1060).

${ }^{a}$ Bennett, S. H., and Furmidge, C. G. L., Nature, 178, 152 (1956).

'North, C., Nuture, 178, 1186 (1956).

'Ross, R. G., and Stewart, D. K. R., Canad, J. Plant Sci., 40, 117 (1960).

- Kearns, H. G. H., and Morgan, N. G., Ann. Rep. Long Ashton Res, Sta. for $1056,145(1957)$.

\section{Accumulation and Transformation of Sugars in Sugar Cane Stalks : Mechanism of Inversion of Sucrose in the Inner Space}

Previous work ${ }^{1-3}$ has shown that sucrose is the sole sugar transferred from the outer space to the inner space of sugar-cane storage tissue disks by an energy-coupled process. Tho outer space was identified tentatively as including the cytoplasm, and the inner space as the vacuolar volume.

By means of tracer studios, glucose and fructoso which oecur in relatively high concentrations in immature tissue were shown to arise from sucrose being inverted in the inner space. It was suggested that inversion may be mediated by a vacuolar invertase, and that an essential step in the maturation process would be masking or loss of invertase ${ }^{3}$.

Hartt ${ }^{4}$ found invertase in green-leaf and dry-leaf portions of sugar-cano stalks, while $\mathrm{Fujii}^{5}$ reported invertase in the rind at the tip of the stalk but absent from the storage tissue in the centre part of the stalk. Two onzymes which synthesize sucrose have been roportod in sugar-cane-uridine diphosphoglucosefructose transglycosylase ${ }^{6}$ and sucrose phosphorylase ${ }^{7}$. Both enzymes catalyse freely revorsible reactions, which togethor with other enzymes could form systems for inverting sucrose.

The mechanism by which sucrose is inverted in storage tissue has been investigated. Initially the activity in crushed cells, juice and cell residues was compared. Radioactive sucrose was used as substrato and inversion followed by measuring the activity in glucose and fructose after chromatographic separation. Approximately 80 per cent of the activity in crushed colls was recovered in juice.

Hydrolysis of uniformly labelled sucrose by cane juice was carried out in the presence of excess unlabelled fructose, with the expectation that asymmotry of labolling in sucrose would develop if either of the sucrose synthesizing enzymes was functional in the system. No asymmetry was observed after $8 \mathrm{hr}$., during which more than 50 per cent of the substrate was hydrolysed (Table 1 ). In a similar experiment no labelled glucose was incorporated into endogenous unlabelled sucrose during a period in which 23 por cont of the sucroso was hydrolysed.

Experiments in which sucrose inversion by dialysed and undialysed juice was compared showed no lowering of activity following dialysis. The effectiveness of dialysis in removing small molecules was indicated by strong sucrose, glucose and fructose spots on paper chromatograms from undialysed juice whereas no sugars were detected in dialysed juice. Both the
Table 1. INCORPORATION OF FROCTOSE INTO SUCROSE-U- ${ }^{24} \mathrm{C}$ DERING INVERSION

Sampling time
(hr.) $\begin{gathered}\text { Percentage of } \\ \text { sucrose inverted }\end{gathered} \begin{gathered}{ }^{14} \mathrm{C} \text { in hydrolysis } \\ \text { products of sucrose/ } \\ \text { glucose/fructose }\end{gathered}$ S.E.

$\begin{array}{lrrr}0 & 0 & 1.08 & 0.07 \\ 1 & 14 & 1.12 & 0.02 \\ 3 & 31 & 1.08 & 0.03 \\ 8 & 58 & 1.06 & 0.02\end{array}$

$1.0 \mathrm{ml}$. juice from immature storage tissues. Additions were $85 \mu \mathrm{gm}$ sucrose-U-14 $\mathrm{C} ; 5,000 \mu \mathrm{gm}$. unlabelled fructose. $T=25^{\circ} \mathrm{C}$. Sucrose in $0.1 \mathrm{ml}$. samples was separated on paper chromatograms, eluted and inverted with analytical invertase. Radioactivity in glucose and fructose moieties of sucrose was determined after separation on paper chromatograms. Results are means of quadruplicate determinations.

sucrose-synthesizing onzymes require dialysable cofactors. Lastly, no activity was detected in boiled juice. All these experiments were carried out with juice from immature storage tissue. The results show that an enzyme of the invertase type is responsible for sucrose inversion.

A comparison was made of tho invertase activity in dialysed juice from storage tissue at different stages of maturity (Table 2). Relatively high activity was found in dialysed juice from very young internodes in which redueing sugar contont is high. No activity was detected in juice from more mature internodos which contain large amounts of sucrose and practically no reducing sugars. The limit of detection of the method was about 10 enzyme units as defined in Table 2.

Table 2. Invertase ACtivity in Diauyged Juice from Storagb 'TISEUE OF DUYYERENT AQES

$\begin{array}{cccc}\begin{array}{c}\text { Internode } \\ \text { No. }\end{array} & \begin{array}{c}\text { Internode diameter } \\ \text { (cm.) }\end{array} & \begin{array}{c}\text { Internode length } \\ \text { (cm.) }\end{array} & \begin{array}{c}\text { Enzyme content } \\ \text { invertage } \\ \text { units/ml. juice }\end{array} \\ 5 & 1 \cdot 3 & 2 \cdot 5 & 374 \\ 6 & 1 \cdot 9 & 10 \cdot 1 & 108 \\ 8 & 3 \cdot 2 & 14 & \text { nil } \\ 11 & 3 \cdot 2 & 14 & \text { nil }\end{array}$

Storage tissue was ground and centrifuged at $1,800 \mathrm{~g}$ for $5 \mathrm{~min}$. $0.7 \mathrm{ml}$. juice was removed and dialysed against distilled water for $3 \mathrm{hr}$. at $25^{\circ} \mathrm{C}$. and with rapid stirring. The volume of the dialysed juice was noted, and $0.5 \mathrm{ml}$. samples taken for assay of invertase. The unit of invertase activity is arbitrarily deflned as the anount of enzyme inverting $1.0 \mu \mathrm{gm}$. sucrose $/ \mathrm{hr}$. in 0.83 per cent sucrose at
$25^{\circ} \mathrm{C}$. Assays carried out under toluene, with sucrose-14 $\mathrm{C}$ as substrate. Radioactivity was determined in reducing sugars after separation on paper chromatograms. Reaction-rates for internodes 5 and 6 were constant over $27 \mathrm{hr}$.

The failure to detect invertase in immature storage tissue $^{5}$ was probably due to insufficient sensitivity of the method used. The amount of enzyme present is very small but appears to be adequate to account for previous observations. In young tissue which contained $2.8 \mu M$ sucrose/25 disks the turnover timo for tho sucrose pool was $8.6 \mathrm{hr} .^{3}$. This amount of tissue contained $0.30 \mathrm{ml}$. juice. Taking the figure of 374 invertase units $/ \mathrm{ml}$. juice from a young internode (Table 2), approximately $8 \mathrm{hr}$. would be required for the inversion of $2.8 \mu M$ sucrose. Hence the present results are in accord with the hypothesis that inversion of sucrose in the inner space (vacuole) of im. mature storage tissue is mediated by invertase, and the enzyme is inactivated during the maturation process.

\section{K. T. Glasziou}

David North Plant Research Centre,

Colonial Sugar Rofining Co., Ittd., Brisbano.

' Bieleski, R. J., A ustral. J. Biol. Sci., 13, 203 (1980).

${ }^{2}$ Glasziou, K. T., Plant Physiol., 85, 895 (1900).

${ }^{3}$ Glasziou, K. T., Plant Physiol., 38, 175 (1961)

' Hartt, Constance W., Hawaiian Planters' Rec., 47, 118 (1043).

'Fujii, M., J. Agric. Chem. Soc. Japan, 18, 061 (1942).

- Cardini, C. E., Leloir, L. F., and Chiroboga, J., J. Bioi. Chem. 214, 149 (1955).

'Shukla, J. P., and Prabhu, K. A., Experientia, 16, 202 (1960). 